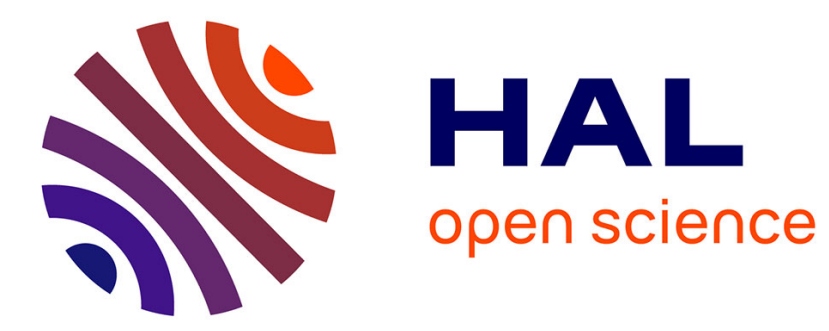

\title{
Studies of infrasound production and perception by the Capercaillie (): a reply to Freeman and Hare
}

\author{
Geoffrey A. Manley, Manfred Lieser, Peter Berthold
}

\section{To cite this version:}

Geoffrey A. Manley, Manfred Lieser, Peter Berthold. Studies of infrasound production and perception by the Capercaillie (): a reply to Freeman and Hare. Journal für Ornithologie = Journal of Ornithology, 2011, 152 (3), pp.817-818. 10.1007/s10336-011-0710-5 . hal-00699212

\section{HAL Id: hal-00699212 \\ https://hal.science/hal-00699212}

Submitted on 20 May 2012

HAL is a multi-disciplinary open access archive for the deposit and dissemination of scientific research documents, whether they are published or not. The documents may come from teaching and research institutions in France or abroad, or from public or private research centers.
L'archive ouverte pluridisciplinaire HAL, est destinée au dépôt et à la diffusion de documents scientifiques de niveau recherche, publiés ou non, émanant des établissements d'enseignement et de recherche français ou étrangers, des laboratoires publics ou privés. 
Studies of infrasound production and perception by the Capercaillie (Tetrao urogallus): A reply to Freeman and Hare.

Geoffrey A. Manley, Manfred Lieser, Peter Berthold

G. A. Manley (Corresponding author)

Cochlear and Auditory Brainstem Physiology, IBU, Faculty V, Carl von Ossietzky University, Oldenburg, Germany

e-mail: geoffrey.manley@wzw.tum.de

\section{Lieser}

Franz-Xaver-Oexle-Str. 30, D-78256 Steisslingen, Germany

\section{P. Berthold}

Max-Planck-Institute for Ornithology, Schlossallee 2, 78315 Radolfzell, Germany

In their letter to the editor (Freeman and Hare, 2011), Freeman and Hare suggest that the technical procedures used in our study of infrasound responses in the Capercaillie (Tetrao urogallus) were improper and at least inadequate to answer the questions posed. We reject their comments unreservedly, for the following reasons:

1. Freeman and Hare (2011) assume that we utilized one particular kind of automotive loudspeaker for this study. In fact we used the "Infinity Kappa Sub" subwoofer designed for use in buildings (Harman Deutschland GmbH \& Co. KG, Hünderstraße 1, D-74080 Heilbronn). This loudspeaker has far better technical specifications than Freeman and Hare (2011) assumed, i.e., " $\pm 3 \mathrm{~dB}$ from 25 to $150 \mathrm{~Hz}$ " and certainly does not show a spectrum that "rolls off dramatically at frequencies below 100Hz" (Freeman and Hare, 2011). Indeed, without appropriate levelling adjustments, this speaker has it strongest spectral component near $40 \mathrm{~Hz}$. The figure shows a spectrum of the "Flutter-jump" behaviour of a male Capercaillie played back using the Infinity Kappa Sub loudspeaker and as recorded with our equipment as described (Lieser et al., 2006). The spectral components recorded in the field in our first study (Lieser et al., 2005) are clearly present in the playback, the lowest harmonic component being near $9 \mathrm{~Hz}$. In the aviary used for playback studies, the achievable sound pressures are shown in figure 1.

2. Freeman and Hare (2011) inexplicably imply that we are unaware that "human hearing falls off below $40 \mathrm{~Hz} "$ and therefore would have needed specialized equipment to detect the ultrasound. They thus completely ignore the details provided on the sound-recording equipment used in both studies. The microphone used had a flat spectrum from $3.15 \mathrm{~Hz}$ to $20 \mathrm{kHz}$ and, under field conditions and with the amplifier and recording system used, was ample for sound pressures across this spectrum that exceeded 10 - $20 \mathrm{~dB}$ SPL. As can be seen in the figure, the equipment clearly separated the harmonic spectral components $9 \mathrm{~Hz}, 18 \mathrm{~Hz}, 27 \mathrm{~Hz}$, etc.

We do, however, agree fully with Freeman and Hare (2011) that "It is important to properly test the responses of Capercaillie to infrasound..." and respectfully suggest that this is in fact what we have already done. 
Nonetheless, we would of course greet all further studies aimed at answering still open questions related to infrasound production and perception by the Capercaillie.

References

Freeman AR, Hare F (2011) Infrasound in the flutter-jump display of Capercaillie (Tetrao urogallus): signal or artefact? J Ornithol. XXXXXXXX

Lieser M, Berthold P, Manley GA (2005) Infrasound in the capercaillie (Tetrao urogallus). J Ornithol 146:395-398.

Lieser M, Berthold P, Manley GA (2006) Infrasound in the flutter jumps of the capercaillie (Tetrao urogallus): apparently a physical by-product. J Ornithol 147:507-509.

Figure caption:

Fig. 1: Spectrum of a male Capercaillie flutter-jump display played back through the Infinity Kappa Sub loudspeaker, re-recorded at $3 \mathrm{~m}$ distance.

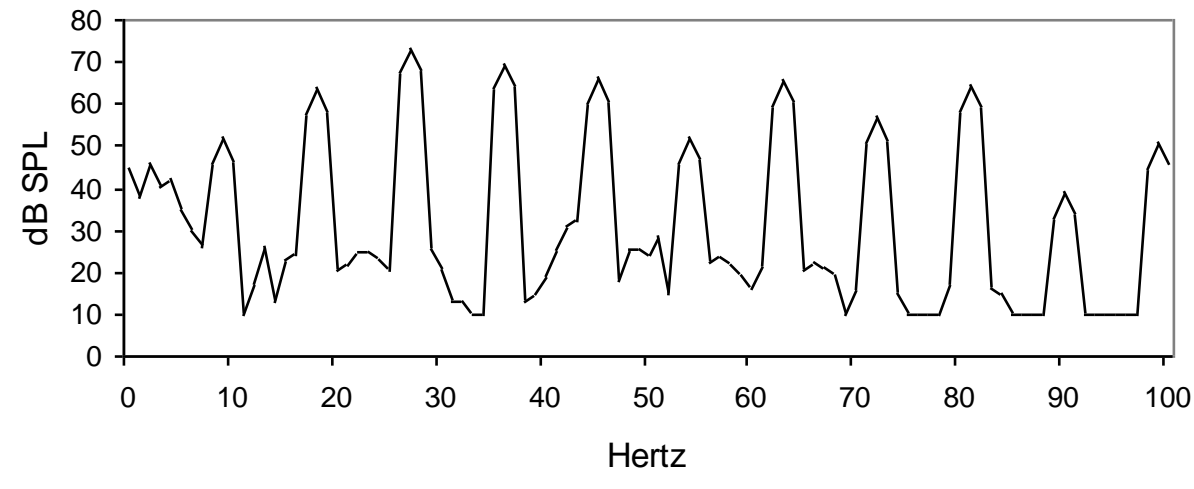

